\title{
Teaching Video NeuroImages: When the Shoulder Inspires
}

\section{A Case of Breathing Arm}

Jennifer L. McKinney, MD

Neurology ${ }^{\circledR}$ 2021;97:e224. doi:10.1212/WNL.0000000000011755

A 6-month-old girl presented with left arm weakness dating from birth. She had significant elbow flexion and shoulder abduction weakness and mild finger, wrist, and arm extension weakness. EMG/nerve conduction studies were pursued to evaluate extent of injury and demonstrated panplexus injury. Median, lateral antebrachial cutaneous, and radial sensory responses were abnormal, and EMG showed evidence of reinnervation in C5-T1 innervated muscles with ongoing denervation in C5-6 innervated muscles. Spontaneous deltoid firing coincident with inspiration was observed on EMG (video 1). This phenomenon, "breathing arm," occurs in obstetric and nonobstetric plexopathies when the C5 nerve root is injured proximal to the phrenic nerve origin. In breathing arm, aberrant regeneration of fibers originally supplying the phrenic nerve supplies upper trunk muscles, resulting in synkinesis with contraction of upper trunk muscles with inspiration. An alternative explanation is that this represents a compensatory response to diaphragmatic inadequacy. However, with no clinical evidence of respiratory insufficiency, aberrant reinnervation is favored. Respiratory synkinesis is significant when considering surgery as this indicates severe proximal root or trunk injury. ${ }^{1,2}$

\section{Study Funding}

No targeted funding reported.

\section{Disclosure}

J.L. McKinney reports no disclosures relevant to the manuscript. Go to Neurology.org/ $\mathrm{N}$ for full disclosures.

\section{Appendix Author}

\begin{tabular}{lll}
\hline Name & Location & Contribution \\
\hline $\begin{array}{l}\text { Jennifer L. } \\
\text { McKinney, MD }\end{array}$ & $\begin{array}{l}\text { Nationwide Children's Hospital/The Ohio State } \\
\text { University College of Medicine }\end{array}$ & $\begin{array}{l}\text { Designed and conceptualized study, drafted } \\
\text { and edited the manuscript }\end{array}$ \\
\hline
\end{tabular}

\section{References}

1. Swift TR. The breathing arm. Muscle Nerve. 1994;17(1):125-129.

2. Friedenberg SM, Hermann RC. The breathing hand: obstetric brachial plexopathy reinnervation from thoracic roots? J Neurol Neurosurg Psychiatry. 2004;75(1):158-160.
Correspondence Dr. McKinney Jennifer.mckinney@ nationwidechildrens.org

\section{MORE ONLINE}

Video

$\rightarrow$ Teaching slides links.lww.com/WNL/ B341 


\section{Neurology}

Teaching Video NeuroImages: When the Shoulder Inspires: A Case of Breathing Arm Jennifer L. McKinney

Neurology 2021;97;e224 Published Online before print February 26, 2021

DOI 10.1212/WNL.0000000000011755

This information is current as of February 26, 2021

Updated Information \& Services

References

Subspecialty Collections

Permissions \& Licensing

Reprints including high resolution figures, can be found at: http://n.neurology.org/content/97/2/e224.full

This article cites 2 articles, 1 of which you can access for free at: http://n.neurology.org/content/97/2/e224.full\#ref-list-1

This article, along with others on similar topics, appears in the following collection(s):

EMG

http://n.neurology.org/cgi/collection/emg

Information about reproducing this article in parts (figures,tables) or in its entirety can be found online at:

http://www.neurology.org/about/about_the_journal\#permissions

Information about ordering reprints can be found online:

http://n.neurology.org/subscribers/advertise

Neurology ${ }^{\circledR}$ is the official journal of the American Academy of Neurology. Published continuously since 1951, it is now a weekly with 48 issues per year. Copyright @ 2021 American Academy of Neurology. All rights reserved. Print ISSN: 0028-3878. Online ISSN: 1526-632X.

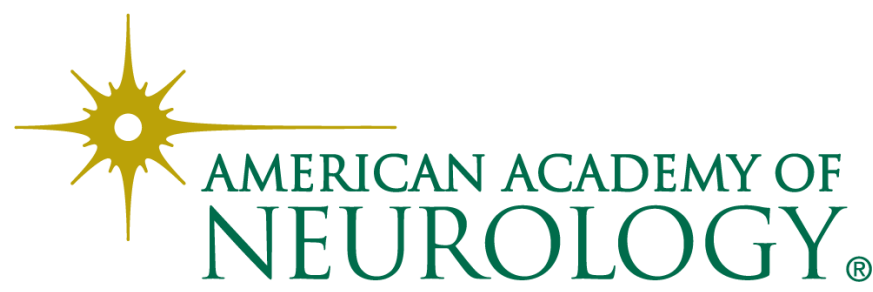

